\title{
Original
}

\section{APPEARANCE OF DENTAL CARIES VERSUS AMALGAM LESION IN A COMMUNITY.}

\author{
By
}

\section{Masao ONISI* and Hiroshi TANI*}

\begin{abstract}
In order to compare the incidence of 1st molar caries and incidence of secondary amalgam caries appearing on the same tooth, yearly changes of the carious incidence were obtained from the protocols made at school dental examination of 344 children at Semmaya and amalgam fillings of 579 school children at the same town were examined one year after treatment. The rate of intact teeth was decreased in constant rate as shown in the formula, $\log \mathrm{P}=1.989-0.051 \mathrm{~T}$, where $\mathrm{P}$ means remaining intact teeth rate, $\mathrm{T}$ means school year, and constant 0.051 may denote real incidence of the 1 st molar of the given population. On the contrary, resistance against amalgam injury decreased with ageing of the children $(\mathrm{P}=$ $1.76+32.271 / \mathrm{T})$. The present findings may conclude that even if the resistance against amalgam attack may be ascribed to the known chemical and physical changes appearing after tooth eruption, but host resistance against carious attack may not be always parallel with such physical changes of the tooth. It was estimated that the cariogenecity of a population in a certain community would remain constant during fairly long period of time, and additionally, the constant incidence was obtained after similar mathematical treatment of prevalence rates surveyed from each school year class. The real incidence of another tooth was also estimable from the similar formula but involvement of more cariogenic factors would be considered. Finally incidence of the amalgam injury should be denoted by a function of ageing.
\end{abstract}

う蝕形成とアマルガムニ次損傷の違い

大西正男・谷 宏

第一大曰歯のう蝕発生率を, 同じ歯の裂溝ら蝕に充填したアマルガム二次う蝕の発生率と比較 する目的で, 同じ地域（岩手県千厩町）の小児について, 前者は Retrospective follow-up 法で, 後 者は小学生のアマルガム充填後 1 年目の二次ら蝕を測定した。健康な第一大臼歯は毎年一定比率で減 少即ち真の5蝕発生率はこの期間一定と見なされる $(\log \mathrm{P}=1.989-0.051 \mathrm{~T} ; \mathrm{P}$ 位健康歯率, Tは学 年，0.051 は集団の第一大臼歯の真の発生率）のに対し，アマルガム二次う蝕は年齢に反比例して減 少 $(\mathrm{P}=1.760+32.2701 / \mathrm{T} ; \mathrm{P}$ はアマルガム二次5蝕の発生率, $\mathrm{T}$ は学年) した。この結果は, 従来 から知られている歯の萠出後に 現われる歯質の化学的並びに物理的変化は凡てアマルガム二次ら蝕の 病因に関係する因子でありえても，う蝕の発生とは一次的には関係のないものであることを示す。集

* 東京医科歯科大学歯学部予防歯科学教室（主任：大西正男教授）

Department of Preventive Dentistry, School of Dentistry, Tokyo Medical and Dental Unizersity, Yushima 1-chome, Bunkyo-ku, Tokyo.

昭和 44 年 10 月 1 日受付 
団内のう蝕形成因子は地域社会にあつてはかなり長い期間変らないと推定されるが，学年別有病率を 連続さしても，同じ関係が得られた。第一大田歯以外の歯では抵抗因子が複雑になつていると考察さ

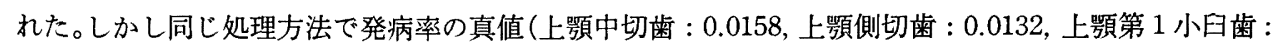
0.007）を計算することができた。またアマルガム二次う蝕の発生率は年齡の函数として 表現す心゙き であると考察された。

Two opinions of caries incidence of an annual increment of cavities appearing in some tooth category in permanent dentition which reduces with age are presently being debated. The first one is that the tooth acquired some caries resistance according to the length of the post-eruptive period ${ }^{11}$. The other, proposed by Reid and Grainger ${ }^{2}$, estimates a constant caries attack rate from certain mathematical treatment of survey results of smooth surface caries in molars.

Amalgam filling for treatment of dental decay is widely applied in clinical dentistry, has been a valuable contribution to public health in New Zealand ${ }^{3)}$, and has been proposed by Hyatt as a possible prophylactic treatment of the fissure ${ }^{4)}$. A propensity, however, to produce a secondary lesion around the in-laid amalgam would inhibit the wide spread use of this material and would hinder the development of early detection and prompt treatment of dental caries. Thus, while many dentists discuss amalgam filling, its technique, incidence, or the material itself, few papers are directed to the problem itself, and few treat it to be different from real caries.

Even if the amalgam lesion is equivalent to carious lesion, in any respect, a follow-up study after amalgam filling would be useful for testing caries preventive agents, at least for better knowlegde of the probability of cariogenic attack. The present report is concerned with the yearly increment of fissure caries of the first molar, in comparison with the mode of incidence of the secondary lesion adjacent to amalgam laid in the first molar, of school children living in the same town.

\section{Meterial and methods}

Carious cavities appeared on the 1st molars of 601 school children, aged from 6 to 12 years old, at Semmaya, Iwate Prefecture, and were treated by authorized amalgam in-lay technique in June, 1965, and appearance of the secondary lesion was examined 12 months later. In the same town, the accumulation of experienced caries of 344 children, aged 6 years old, was retrospectively followed up for nine years on the protocols recorded by the school dentist. On the other hand, 771 school children, aged from 6 to 12 years old, of Sumon, Niigata Prefecture, were dentary examined by means of a mirror and an exploration technique which utilizes bite-wing radiograms, in May, 1968, to summarize caries prevalences in each age group.

\section{Findings}

Secondary lesions following amalgam filling which appeared during the next 12 months were summarized, as illustrated in table 1, showing a tendency of lower incidence at the higher age group. 
Table 1. Incidence of secondary lesion around the amalgam filling on the 1st molar.

(Semmaya, Iwate Prefecture)

\begin{tabular}{|c|c|c|c|c|c|c|c|c|}
\hline \multirow{2}{*}{ School year, at the time of filling. } & \multicolumn{6}{|c|}{ Primary school } & \multirow{2}{*}{$\begin{array}{c}\begin{array}{l}\text { High } \\
\text { school }\end{array} \\
1\end{array}$} & \multirow{2}{*}{ Total } \\
\hline & 1 & 2 & 3 & 4 & 5 & 6 & & \\
\hline $\begin{array}{l}\text { No. of examined } M_{1} \text { of amalgam } \\
\text { filling }\end{array}$ & 48 & 63 & 89 & 87 & 60 & 121 & 111 & 579 \\
\hline No. of $M_{1}$ of the 2ndary lesion & 16 & 16 & 11 & 8 & 2 & 9 & 6 & 68 \\
\hline $\begin{array}{l}\text { Incidence of the 2ndary lesion } \\
(\%)\end{array}$ & 33.3 & 25.4 & 12.4 & 9.3 & 3.3 & 6.5 & 5.7 & 11.8 \\
\hline
\end{tabular}

Table 2. Decrease of intact $M_{1}$, with ageing. (Semmaya, Iwate Prefecture)

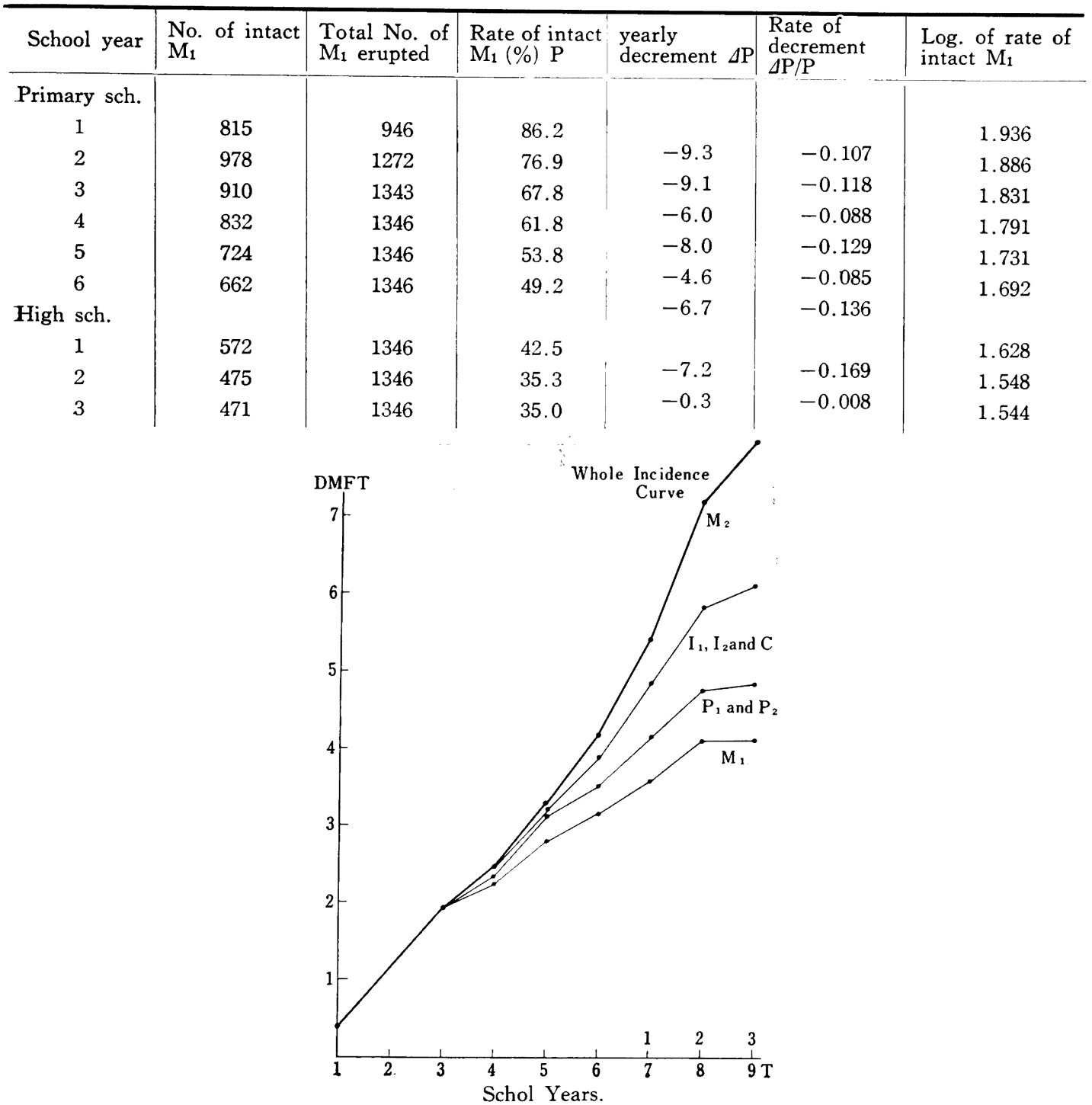

Fig. 1. Crude incidence curve of DMFT during 8 years at Semmaya, reproduced by the retrospective follow-up study 
Table 3. Prevalence of intact $M_{1}$ at Sumon, Niigata Prefecture, 1968.

\begin{tabular}{c|c|c|c|c}
\hline School year & No. of intact $\mathrm{M}_{1}$ & $\begin{array}{l}\text { Total No. of } \\
\mathrm{M}_{1} \text { erupted }\end{array}$ & $\begin{array}{l}\text { Rate of intact } \\
\mathrm{M}_{1}(\%)\end{array}$ & $\begin{array}{l}\text { Log. of rate of } \\
\text { intact } \mathrm{M}_{1}\end{array}$ \\
\hline 1 & 65 & 299 & 78.3 & 1.894 \\
2 & 122 & 407 & 70.0 & 1.845 \\
3 & 224 & 491 & 54.4 & 1.736 \\
4 & 315 & 539 & 41.6 & 1.619 \\
5 & 331 & 548 & 39.6 & 1.598 \\
6 & 433 & 688 & 27.0 & 1.433
\end{tabular}

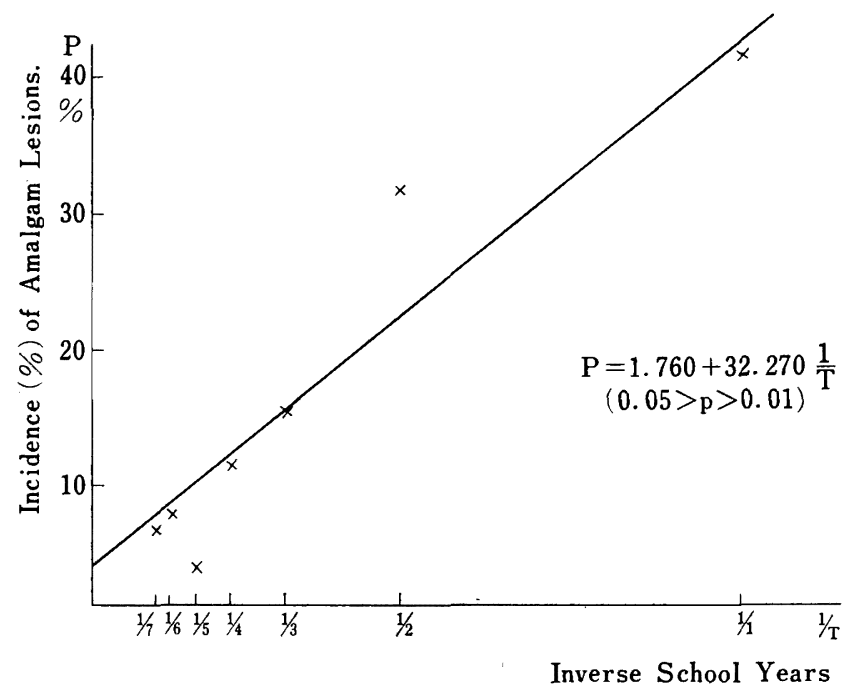

Fig. 2. Lineality of incidence (\%) of amalgam lesion against inverse school years

The retrospective survey on the carious experience of the children looked lineal, as. shown in figure 1, which has been analysed into the involvement of each component tooth. Table 2 indicates the results of the 1st molar examination from figure 1 . The ratio of intact teeth to total erupted 1st molar, at a given age, decreased against ageing. Prevalences of the ratio of intact 1st molar of each age group were summarized, and are illustrated on table 3. A lower rate of intact 1 st molar was found in the more aged group.

\section{Discussion}

Reviews of the Shimeikai's summer assistance program ${ }^{5)}$ also showed that the incidence of secondary amalgam lesion decreased against age. In order to ascertain implications suggested by table 1 , incidences of secondary lesion following amalgam filling were plotted against inverse age (Fig. 2), and the lineality of the relationship was proved to be significant to $0.05>\mathrm{p}>0.01$. This conclusion proposes new indexing to express the incidence of secondary lesion of amalgam filling as a function of the average age of the group under treatment. It also suggests changes in the application of this technique in public health programs. 
On table 2 , the annual decrement $(\Delta \mathrm{P})$ of intact 1 st molars was calculated, and the ratio of $\Delta \mathrm{P}$ to each incidence, $\Delta \mathrm{P} / \mathrm{P}$, was found to be almost constant. The relationship, then, can be expressed as : $\Delta \mathrm{P} / \mathrm{P}=-\mathrm{k}$. Since $\Delta \mathrm{P}$ means $\mathrm{dP} / \mathrm{dT}$, the following differential equation is established, substituting for $\Delta \mathrm{P}$. Where $\mathrm{T}$ means time in school years.

$$
\begin{aligned}
& \frac{\mathrm{dP}}{\mathrm{dT}} / \mathrm{P}=-\mathrm{k} \\
& \frac{1}{\mathrm{P}} \mathrm{dP}=-\mathrm{k} d \mathrm{~T} \\
& \int \frac{1}{\mathrm{P}} \mathrm{dP}=-\mathrm{k} \int \mathrm{dT} \\
& \log \mathrm{P}=-\mathrm{kT}+\mathrm{C}
\end{aligned}
$$

Formula 2 is a solution of formula 1 , showing a lineal relationship if the logarithm of the intact tooth of any age group is plotted against the age of the group. The minimum square method applied to the results illustrated in table 2 proved the actuality of formula 2 , as shown in figure 3 , where the slope $(\mathrm{k})$ means caries real incidence of the 1st molar.

The real incidence induced from actual measurement would be very similar to the attack rate (Reid and Grainger ${ }^{2}$ ) which was introduced by a deductive method and found to be applicable to smooth surface caries in the molar. But prerequisite of his attack rate might be constant resistance of the teeth. The above discussion seems to establish that at least in the 1st molar, the decrease in yearly increment of caries is only an apparent phenomenon. Accordingly, a real incidence of the 1 st molar to caries was sought in

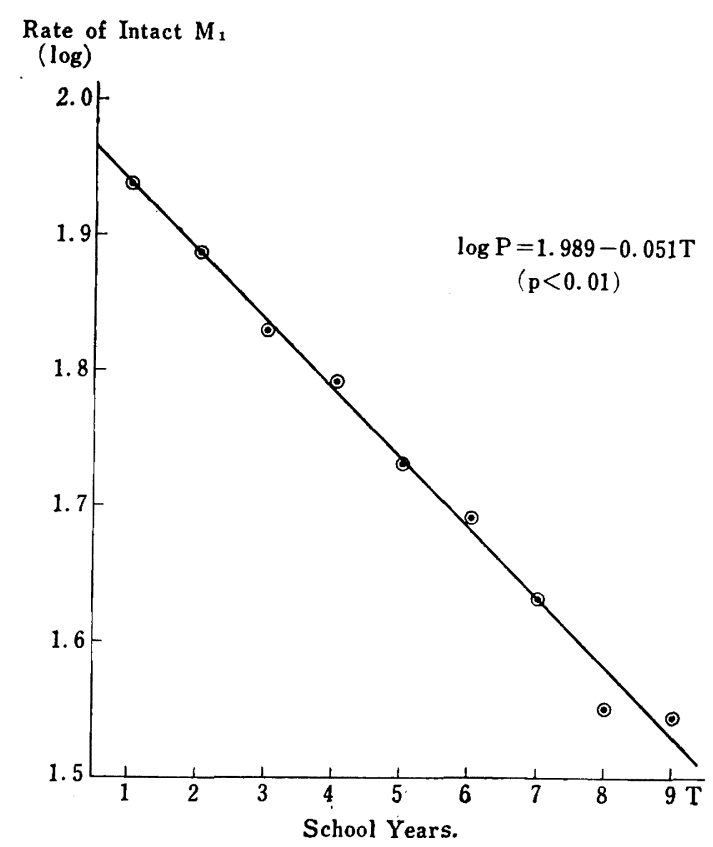

Fig. 3. Lineality of log. intact $M_{1}$ rate with school years, at Semmaya 

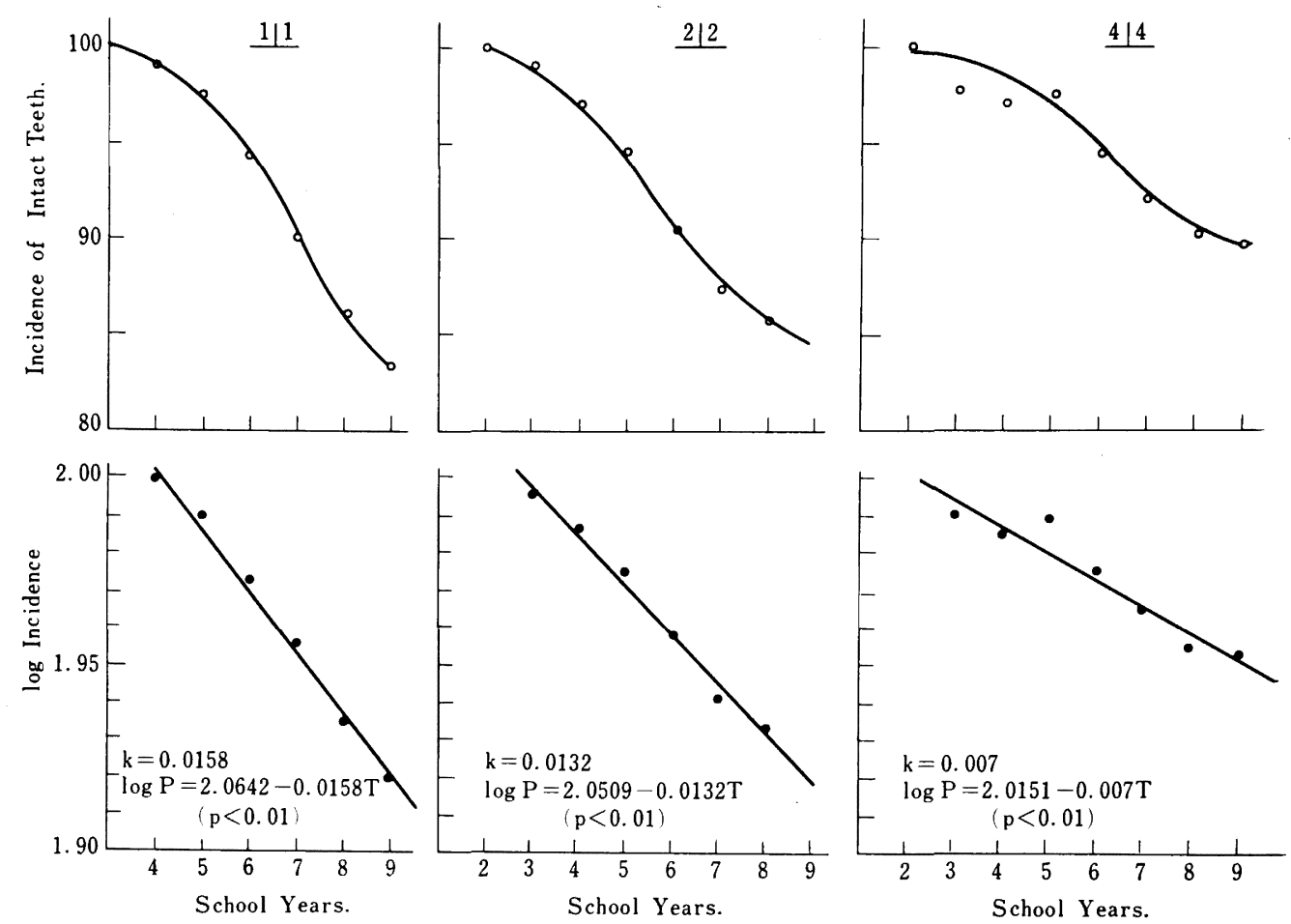

Fig. 4. Sigmoid relation of decreasing intact teeth with ageing and obtained real incidence of the maxillary medial and lateral incisors and 1 st premolar

a different tooth category. The retrospective survey on the intact rates of upper incisors and 1st premolar seemed sigmoid, as shown in figure 4. As discussed in a previous paper $^{6)}$, the sigmoid rule in kinetics denotes involvement of more factors, for instance the time lag for contact, due to growth, of neighboring incisors after eruption. Even though it is reason, real incidence of maxillary medial, lateral incisors and 1st premolars were practically obtainable in respect of $\mathrm{k}$, as shown in figure 4, indicating incidence order of these teeth $\left(\mathrm{M}_{1}<\mathrm{I}_{\text {lsup }}<\mathrm{I}_{\text {2sup }}<\mathrm{P}_{\text {lsup }}\right)$. Here $\mathrm{k}$ of $\mathrm{M}_{1}$ mainly may indicate incidence at fissure, because prevalence of proximal surface caries of the 1 st molar was estimated only $8 \%$ at Sumon, 1968. On the contrary, $\mathrm{k}$ of maxillary medial and lateral incisors would mean incidence of smooth surface of these teeth. Prevalences on the intact rate of the 1st molar in different groups of various ages gave linear relationships, but different slopes after similar treatment of the results obtained at Sumon (figure 5).

Here the discussion comes to the dissimilarity between constant incidence of the host against cariogenic attack and the acquirement of resistance with ageing against amalgam injury. It should be stressed that some references on age are dependant on change in the tooth substance, for instance, post-eruptive maturation or changes of the mineral phase of enamel ${ }^{7}$, increasing fluorine concentration in the enamel surface ${ }^{8)}$, increasing electric resistance of the fissure ${ }^{81}$, hardness ${ }^{10)}$, and the decrease of $\mathrm{CO}_{2}$ in the enamel surface ${ }^{11}$. These chang- 


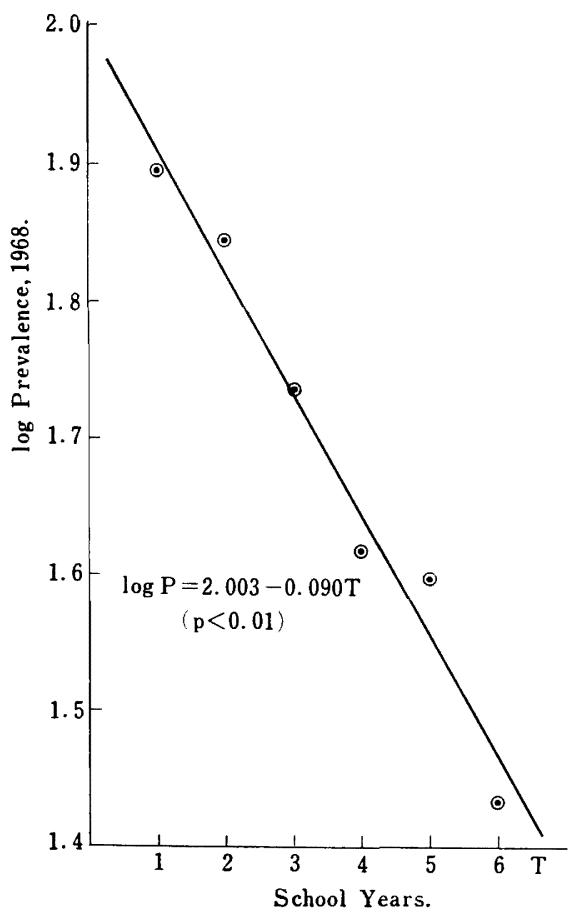

Fig. 5. Lineality of log. prevalence of intact $M_{1}$ against each groups of school years, at Summon, 1968

es may not excert primarily on the lessening of caries susceptibility of the tooth, but on increasing resistance to amalgam injury.

\section{References}

1）竹内光春：口腔衛生学, 歯界展望, $18 ; 193-$ 197, 1957.

2) Reid, D. B. and Grainger, R. M.: Variations in the caries susceptibility of children's teeth, Human Biology, 27 ; 1-11, 1955.

3) Saunders, J. L. : The New Zealand School Dental Service, R. E. Owen Gov. Print., Wellington, 1963. (竹内光春訳)

4) Hyatt, T. P. : Prophylactic odontotomy: The Cutting into the tooth for the prevention of disease, Dent. Cos., 234-241, 1923.

5）紫芳会活動報告書，1962年度.

6) Onisi, M., Ozaki, F. and Okano, M.: Prevention of experimental rat caries. IV Two different lesions in dentin appeared on the fissure caries of rats, J. J. Dent. Hlth., 18;
39-53, 1968.

7) Brudevold, F.: Changes in enamel with age, Univ. Rochester Dental Res. Fellowship Prog., Proced. 25 th year celebration, 185-192, 1957.

8) Brudevold, F., Steadman, L. T., and Smith, F. A. : Inorganic and organic compositions of teeth structure. Ann. New York Acad. Sc., 85 ; 110-132, 1960.

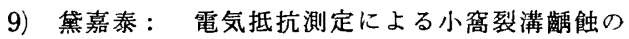
診断法. 保存歯会誌, 7; 50-69, 1964.

10）加藤一男：歯質の物理化学的性質, 口病誌, 29 ; 56-69, 1962.

11) Little, M. F. and Brudevold, F. : A study of inorganic carbon dioxide in intact human enamel. J. D. Res., 37 ; 991-1000, 1958. 